\title{
A Study on Entrepreneurial Intentions among B-school Students in India
}

\author{
Raghavendra Sode ${ }^{1}$, Kalaa Chenji ${ }^{2}$, Laila Memdani ${ }^{3}$, Mushtakhusen S. M. ${ }^{4}$ \\ \{ soderaghavendra@gmail.com ${ }^{1}$, chenjikala@gmail.com², \\ lailam@ibsindia.org ${ }^{3}$,mushtaque@ibsindia.org $\left.{ }^{4}\right\}$ \\ ${ }^{1,2}$ Department of Human Resources, ${ }^{3}$ Deparment of Economics, ${ }^{4}$ Department of Soft Skills, \\ ICFAI Business School, Telangana, India
}

\begin{abstract}
Choosing entrepreneurship as a career is a risk-taking process for Bschool students especially for the students in developing countries like India. Even though, the entrepreneurship program delivers theoretical and practical exposure through business plans and competitions and makes students look at entrepreneurial activity as one of the career paths. There is a need to understand the underlying reasons for choosing entrepreneurial activities among B-school students. Therefore, the current study focuses to understand the underlying reasons for B-school students to choose an entrepreneurial activity, identify the factors and link with entrepreneurial intentions. The study uses both qualitative and quantitative methods of research to achieve the objective. Five factors identified include challenge, autonomy, self-realization, authority, and economic opportunity. The factors are significantly related to entrepreneurial intentions. Further, regression analysis indicates that out of the factors economic opportunity is the strongest predictor of entrepreneurial intentions followed by autonomy, challenge, self-realization, and authority.
\end{abstract}

Keywords: Entrepreneurship, Entrepreneurial Intentions, Challenge, Autonomy, Self-Realization, Authority and Economic Opportunity

\section{Introduction}

Entrepreneurship is gaining more importance among academicians, policy makers and researchers as it is determined and recognizes as a major influencer on economic development [1]. Prevailing cognitive behavioral perspectives on entrepreneurship focused on Entrepreneurial intentions [2]. Since early inception of entrepreneurship program at Harvard Business School it has been well accepted and opted course among business students [3],[4]. Business Schools across the globe emphasize imparting entrepreneurial education to their students and make them capable to start their own business. Entrepreneurship programs covers theoretical and practical exposure giving students ample opportunity to have real time business experience by developing business plans, competing business plan competitions and encouraging students to attract investors to kick start the business [5]. Choosing entrepreneurship as career is risk taking option for B-school students. But to develop and realize an entrepreneurial activity is dependent on once capability to pursue persistently[6]. Therefore, there is a need to understand what factors will lead to entrepreneurial intentions among B-school students. 
Entrepreneurial intention is defined as an individual's desire to initiate a business or to own some one's business[7] and is a well-researched topic. Early stages of entrepreneurial intentions were explained by entrepreneurial event [8] and theory of planned behavior [9],[10],[11]. Entrepreneurial action is likely to occur in the absence of entrepreneurial intention. Therefore, we derive that entrepreneurial intention is precursor for entrepreneurship. According to TPB, subjective norms, personal attitude and perceived behavioral control act as antecedents to entrepreneurial intention [10]. Several studies related entrepreneurial activity emphasized on trait perspective [12],[13].Trait approach could not adequately explain the phenomenon of entrepreneurship[14]. Behavior approach gained momentum in explaining and identifying entrepreneurs [15] and some of the behavioral characteristics liked creating a business [16]; strategic planning [17],in-depth planning [18] were linked to entrepreneurship. And interactional approach [19] linked individual traits with contingent variables experienced by entrepreneur in creating a new venture [20], [3].

Various models explained entrepreneurial intentions like theory of entrepreneurial event (TEE) [8]. Model of executing entrepreneurial idea [21]; expected utility model [22] and TPB model highlighted entrepreneurial intentions leading to entrepreneurship. All these models evolved through contributing some applications, specification with some inconsistencies[23] but did not focus much on understanding the underlying reasons towards entrepreneurial intentions. Many researchers have investigated personal factor leading to entrepreneurial career [24], [25] but there is gap in literature that need to be addressed as previous research has focused on direct determinants and ignored the underlying mechanisms which influence entrepreneurial intentions [26].

The purpose of this study is to explore the reasons for choosing entrepreneurial activity by business graduate students. Further, this study analyzes the factors relationship with entrepreneurial intentions. The study would help to instill and develop entrepreneurial behavior among the business students. This research on what reasons will lead to take up entrepreneurship will help to develop theory and interventions that can be used in academic curriculum and could provide new insights for government to come up with policies encouraging entrepreneurship among B-school students in India.

\section{Literature Review}

Entrepreneurship is self-directed process involving going through new and unusual ideas to be developed in to business and commercialize it to fetch profits. Entrepreneurial activities differ across countries and dependent on many factors [27]. An entrepreneur is not sure of success and takes lot of risk to start the business. Many researchers [6] identified individual capabilities is key factor to be a successful entrepreneur and various personal characteristics were identified and linked with entrepreneurship [25],[24]. Starting from McClelland [28] lot of research on entrepreneurship focused on personality characteristics and its outcomes [29], [30]. Trait approach was exhaustively examined [12],[13].

Entrepreneurship is considered as a complex psychological and cognitive process integrating the different sub-dimensions [31], whereas some researchers found that knowledge, skills and attitudes [32] required to become a successful entrepreneur. Various traits like propensity to take risk, locus of control, values were examined in relationship with entrepreneurship and 
questioned the trait perspective and argued that it is a behavioral aspect associated with an entrepreneur [14] , [15] and was supported by many researchers [16]. Others have [33] linked entrepreneurial behavior with leadership, teamwork, opportunity recognition and creation, innovation, and value creation and identified various types of entrepreneurs.

Process of entrepreneurial begins with student's decision to become an entrepreneur [34]; identifying the opportunity and start the business. Other researchers vastly focused on identifying the entrepreneurial characteristic like need for achievement [28]; Locus of control; risk propensity; and values as key qualities of an entrepreneur. Other have suggested behavior of starting a business explains entrepreneurship[15][16] and explained entrepreneurship using four dimensional model viz., individual characteristic to start venture, creation of organization, environment and the process and termed it as integrative approach to entrepreneurship. Other studies have focused on social dimension and tendency towards action, initiation of entrepreneurial activity are discussed [8]. Some of thestudies identified demographic variables like age, gender education variations towards entrepreneurship, found that education and structural support impact the entrepreneurial intentions [35].

Studies also [36] found similar link between personal attitude, perceived relationships support and perceived behavioral control with entrepreneurial intentions. [37] found parental role model relationship with entrepreneurial intention and in another study [38] linked family, friends support with decision to become an entrepreneur. Entrepreneurial activity leads to economic development and prosperity and alleviation of poverty [39], [40], [41], [2].And more recent studies [19],[20] and [3] found behavioral intentions to become an entrepreneur was less researched and their research tried to understand motivations to become entrepreneur. Entrepreneurial intention is "an individual's desire to initiate a business or to own someone's business"[7]. TPB theory focuses on EI as an individual's inclination towards entrepreneurship as career [42], [10, [9].

Many studies have proved the relationship with perceived behavioral control, subjective norms and personal attitude[7]. Some of other researcher focused on estimated likelihood of EI [43] and others on unconditional measures of intentions. As explained above the researchers focused mainly on behavioral aspects and outcomes of entrepreneurship but the intentions leading to behavior is less researched. Based on the theory of reasoned actions[11] the current study examines the reasons leading to entrepreneurial intentions and find the relationship between the factors and entrepreneurial intentions among B-school students in India.

\section{Research Objective}

The main objective of the study is to find the answer for, why business graduate students want to become entrepreneurs, comprehend the factors and relate the factors to entrepreneurial intentions. Study uses both qualitative and quantitative methods of research to achieve the objectives. 


\section{Research Methodology}

The study focuses on relationship between entrepreneurial intention with factors derived from focus group discussion and factor analysis viz, economic opportunity, challenge, autonomy, authority, and self-realization. [45] model found that attitude, perceived behavior and subjective norms as determinants of self-employment which helps to predict intention to start a business. Katz's [46] model found aspiration, preparation, and jumping as hurdles for self-employment. Starting business involves self-employment but degree of freedom (autonomy) available in the society to start a new business jeopardizes these models.

A study in Uganda and Sri Lank found that opportunity motive other than necessity as a predictor of new business [47]. And another study give importance to economic opportunity, self-realization, authority, social environment, challenge, avoid responsibility and career as other determinants for preferring self-employment among Norwegian business graduates [48]. As we see there is no consistency of variables derived from the studies listed above and in particularly in the context of India, focusing on this current study examines the reasons leading to entrepreneurial intentions among B-school students. With this view we propose the following hypotheses:

\section{Hypotheses}

Ho1: The entrepreneurial intention does not have any relation with economic opportunity.

Ho2: The entrepreneurial intention does not have any relation with challenge.

Ho3: The entrepreneurial intention does not have any relation with autonomy.

Ho4: The entrepreneurial intention does not have any relationship with authority.

Ho5: The entrepreneurial intention does not have any relationship with self-realization.

\section{Analysis}

\section{Level1: Qualitative study to explore the reasons to become entrepreneurs.}

The first part of the study, we generated list of reasons behind business graduate students to become entrepreneur. To achieve the objective, focus group discussion was conducted in two stages. We have eight focus groups two b-schools from each part of India viz., South, North, West and East were selected. The homogeneity characteristic of sampling was maintained and unit of sample were selected based on the conditions that the participants should have entrepreneurship as a specialization or a course of business studies and intentions to become entrepreneur in near future. Participants were encouraged to take part in focus groups voluntarily but the members were restricted to eight with equal participation from both the genders.

In the first stage of Focus group, discussions were conducted with open ended question pertaining to reasons to become entrepreneur and intentions. All the discussions were audio recorded and were transcribed. First author conducted focus group in one each b-schools from South and West part of India while second author conducted focus group in one b-school from 
North and Eastern part of India. Transcripts were interchanged by first and second author to develop thematic frame work independently. Codes derived where categorized based on consent of two authors. In the second stage authors interchanged the locations to conduct focus groups discussion. First author conducted discussions in one b-school each from North and Eastern universities and second author conducted discussions in one b-school each from South and Western part of Indian. During second visit the authors visited other b-school which was not selected during the stage one of the study. Second stage of focus group does not yield any new information and we stopped further focus groups.

All the transcribed codes were in accordance with inductive thematic analysis were the themes from the data lead to the structure and authors do not assume any frame work to draw the themes. The audio recordings were transcribed to reach sensible themes. The process was redone to assure we do not miss out any valuable data and codes were drawn depicting sensible phrases. Similar quoted sentences were put under same codes and codes depicting similarity were collapsed to form meaningful themes. Themes were cross checked for internal consistency and redundancy. External subject experts were approached to get an outsider perspective. The themes identified are depicted in Table. 1.

Tab. 1 Themes

\begin{tabular}{|l|}
\hline \multicolumn{1}{|c|}{ Themes } \\
\hline 1. I will get economic opportunity \\
\hline 2. I receive compensation (other) \\
\hline 3. I like to do exciting job \\
\hline 4. I like to do interesting work activities \\
\hline 5. I will be motivated to work as I like \\
\hline 6. I have freedom \\
\hline 7. I want to be my own boss \\
\hline 8. I want to choose my own work tasks \\
\hline 9. I have power to make decisions \\
\hline 10. I have authority \\
\hline 11. I realize to become an entrepreneur \\
\hline 12. I realize the capabilities to become an entrepreneur \\
\hline 13. I realize to own an enterprise \\
\hline 14. I realize to succeed in entrepreneurial activities \\
\hline
\end{tabular}

\section{Level 2: Data reduction using factor analysis}

Phase 1: Based on the qualitative analysis the themes identified were used to collect data through questionnaire. Questions pertaining to personal information were part of first section in the 
questionnaire which included age, gender, qualification, the second part contained themes identified in level 1 were converted into questions and the last questions were pertaining to entrepreneurial intention. All questions were measured on five point Likert of strongly disagree (1) and strongly agree (5). Data was gathered from 100 respondents from each of the four zones of India viz., South, North, East and West b-school students pursuing entrepreneurship as one of the specialization or course. 157 valid complete questionnaires were retained. The reasons for choosing entrepreneurial activity were factor analyzed by using PCA using Varimax rotation.

The Kaiser-Meyer-Olkin Measure of Sampling Adequacy was at 0.744(Table 2) which implies sample was enough to go for further analysis. Bartlett's results were significant at .05 indicating the correlation matrix is not identical in nature.

Table 2 KMO and Bartlett's Test for sample adequacy

\begin{tabular}{|c|c|c|}
\hline \multicolumn{2}{|c|}{ Kaiser-Meyer-Olkin Measure of Sampling Adequacy. } & .744 \\
\hline \multirow{3}{*}{$\begin{array}{l}\text { Bartlett's Test of } \\
\text { Sphericity }\end{array}$} & Approx. Chi-Square & 958.290 \\
\hline & df & 105 \\
\hline & Sig. & .000 \\
\hline
\end{tabular}

The analysis resulted in identifying five factors. Items with correlations above .5 were grouped under one factor and are depicted in Table 3.According to the results we inferred that the cumulative percentage of variance explained by all the five factors is $70 \%$; the first factor explains $16 \%$ of variation, second factor explains around $16 \%$ and third factor explains $14 \%$, fourth explains $13 \%$ and fifth factor explains $10 \%$ of variance. We also infer that Statement 3 , 4, 5 load on factor 1; items $6,7,8$ belong to factor 2, items 11, 12, 1314 belong to factor 3; item 9, 10 belong to factor 4 and item 1, 2 belong to factor 5 . Factor analysis loading indicate that there is no cross loading of items. The reasons for choosing entrepreneurship were named as Challenge, Autonomy, Self-realization, Authority and Economic opportunity. The results of factor analysis with loading and reliability test results for each of the obtained factors are depicted in Table 3. 


\begin{tabular}{|c|c|c|c|c|c|}
\hline Statement & $\begin{array}{l}\text { Challeng } \\
\text { e (F1) }\end{array}$ & $\begin{array}{l}\text { Autonom } \\
\text { y (F2) }\end{array}$ & $\begin{array}{l}\text { Self- } \\
\text { realizatio } \\
n(\text { F3) }\end{array}$ & $\begin{array}{l}\text { Authorit } \\
\text { y (F4) }\end{array}$ & $\begin{array}{l}\text { Economic } \\
\text { Opportunity } \\
\text { (F5) }\end{array}$ \\
\hline $\begin{array}{l}\text { 1. I will get economic } \\
\text { opportunity }\end{array}$ & & & & & .854 \\
\hline $\begin{array}{l}\text { 2. I receive compensation } \\
\text { (other) }\end{array}$ & & & & & .837 \\
\hline 3. I like to do exciting job & .871 & & & & \\
\hline $\begin{array}{l}\text { 4. I like to do interesting } \\
\text { work activities }\end{array}$ & .835 & & & & \\
\hline $\begin{array}{l}5 . \text { I will be motivated to } \\
\text { work as I like }\end{array}$ & .871 & & & & \\
\hline 6. I have freedom & & .873 & & & \\
\hline $\begin{array}{l}\text { 7. I want to be my own } \\
\text { boss }\end{array}$ & & .878 & & & \\
\hline $\begin{array}{l}\text { 8. I want to choose my } \\
\text { own work tasks }\end{array}$ & & .720 & & & \\
\hline $\begin{array}{l}\text { 9. I have power to make } \\
\text { decisions }\end{array}$ & & & & .843 & \\
\hline 10. I have authority & & & & .784 & \\
\hline $\begin{array}{l}\text { 11. I realize to become an } \\
\text { entrepreneur }\end{array}$ & & & .650 & & \\
\hline $\begin{array}{l}\text { 12. I realize the } \\
\text { capabilities to become an } \\
\text { entrepreneur }\end{array}$ & & & .661 & & \\
\hline $\begin{array}{l}\text { 13. I realize to own an } \\
\text { enterprise }\end{array}$ & & & .778 & & \\
\hline $\begin{array}{l}\text { 14. I realize to succeed in } \\
\text { entrepreneurial activities }\end{array}$ & & & .814 & & \\
\hline Cronbach's Alpha & .842 & .753 & .733 & .799 & .766 \\
\hline
\end{tabular}

\section{Validity and Reliability Tests}

Various studies were referred to develop the questionnaire therefore it meets the content validity. To test the reliability two tests were performed. The first test examined the loadings of 
individual item with respect to the measurement model quality; the items were significant and second test was to perform Cronbach's alpha test of reliability. The five factors identified by factor analysis viz., Challenge, Autonomy, Self-realization, Authority and Economic opportunity were tested for reliability test by using Cronbach's Alpha and their values are .842, $.753, .733, .799$ and .766 respectively (Refer Table 3). The Cronbach's Alpha value for each variable has exceeded accepted alpha value of .700 which indicates the scale is reliable. The results were similar to study of Kolvereid [48].

Tab. 4 The Cronbach's alpha and AVE's

\begin{tabular}{|l|c|c|c|}
\hline \multicolumn{1}{|c|}{ Constructs } & Cronbach's Alpha & AVE & $\begin{array}{c}\text { Square root of } \\
\text { AVE }\end{array}$ \\
\hline Challenge & 0.842 & 0.692 & 0.831 \\
\hline Autonomy & 0.753 & 0.784 & 0.885 \\
\hline Self-realization & 0.733 & 0.715 & 0.845 \\
\hline Authority & 0.799 & 0.794 & 0.891 \\
\hline Economic Opportunity & 0.766 & 0.734 & 0.856 \\
\hline $\begin{array}{l}\text { Entrepreneurial } \\
\text { Intention }\end{array}$ & 0.987 & 0.741 & 0.860 \\
\hline
\end{tabular}

Further, to verify the validity of the measurement, [49] average variance extracted (AVE) was conducted to examine the discriminant validity. The AVE explains the variance of constructs through its items relative to variance due to error of measurement. To verify this discriminant validity, the square root of a construct's AVE must be greater than the correlation between the construct and other constructs. For example, square root of AVEs for two constructs challenge and entrepreneurial intentions are 0.831 and 0.860 as depicted in Table 4 , which are more than the correlation between them, 0.788 as in Table 5. And the results for all other constructs also project similar results; this implies there is adequate discriminant validity between the constructs of the study. The AVE values of the constructs are $0.692,0.784,0.715,0.794,0.734$, and 0.741 respectively and are greater than 0.5 . It indicates acceptable convergent validity of the measurements. Thus, we verify the validity and reliability of the construct used in the study. 
Table 5. Correlation Matrix

\begin{tabular}{|c|c|c|c|c|c|c|}
\hline & EI & $\begin{array}{c}\text { Economic } \\
\text { opportunity }\end{array}$ & Challenge & Autonomy & Authority & $\begin{array}{c}\text { Self- } \\
\text { realization }\end{array}$ \\
\hline EI & 1 & $0.834^{* *}$ & $0.788^{*}$ & $0.626^{* *}$ & $0.747^{* * *}$ & 0.763 \\
\hline $\begin{array}{c}\text { Economic } \\
\text { opportunity }\end{array}$ & & 1 & $0.198^{*}$ & -0.07 & 0.11 & 0.077 \\
\hline Challenge & & & 1 & $0.177^{*}$ & 0.1 & $0.340^{* *}$ \\
\hline Autonomy & & & & 1 & $0.575^{* *}$ & $0.464^{* *}$ \\
\hline $\begin{array}{c}\text { Authority } \\
\text { realization }\end{array}$ & & & & & & 1 \\
\hline
\end{tabular}

** Correlation is significant at the 0.01 level (2-tailed)

* Correlation is significant at the 0.05 level (2-tailed)

\section{Correlation Results}

Table 5 depicts the Pearson correlation between the variables of the study. The hypotheses results are as follows: The results of first hypotheses indicates that, there exists strong correlation between economic opportunity and entrepreneurial intentions $(\mathrm{r}=.834, \mathrm{n}=157, \mathrm{p}<$ $0.01)$; the relationship is strong and significant; hence the null hypothesis is rejected. The results of second hypothesis indicates that, there exists correlation between challenge and entrepreneurial intentions $(\mathrm{r}=.788, \mathrm{n}=157, \mathrm{p}<0.01)$; the correlation is strong and significant; hence the null hypothesis is rejected. The third hypothesis analysis indicates a correlation between autonomy and entrepreneurial intentions $(\mathrm{r}=.626, \mathrm{n}=157, \mathrm{p}<0.01)$; the correlation is strong and significant; hence the null hypothesis is rejected. Fourth hypothesis analysis indicate a correlation between authority and entrepreneurial intention $(r=.747, n=157, p<0.01)$, the relationship is moderate and significant, hence the null is rejected. The fifth hypothesis result indicate that, there exists correlation between self-realization and entrepreneurial intention $(\mathrm{r}=$ $.763, \mathrm{n}=157, \mathrm{p}<0.01$ ); the relationship is strong and significant; hence the null hypothesis is rejected.

\section{Regression Analysis}

Table 6 gives summary of the regression model of the study. The five independent variables or predictor's namely economic opportunity, challenge, autonomy, authority and self-realization are significantly able to explain the impact on dependent variable i.e. entrepreneurial intentions.

The $\mathrm{R}$ value of .462 indicates correlation between the independent and dependent variables. The value of $\mathrm{R}$ square, which gives the percentage of variance explained by the independent variables or predictors, which is about $46.2 \%$ on dependent variable. The adjusted $\mathrm{R}$ square value, which is $21.4 \%$, indicates the variance explained by five independent variables of the study is able to effect entrepreneurial intentions. 
The beta values of five independent variables are: economic opportunity, $(\beta=.420)$; challenge $(\beta=.329)$; autonomy $(\beta=.352)$; authority $(\beta=.139)$; and self-realization $(\beta=.196)$ which indicates that out of the independent variables economic opportunity is strongest variable to explain the phenomenon followed by autonomy, challenge, self-realization and authority. The $\mathrm{F}$ value for the model is 21.47 at .000 significant levels.

Table 6. Multiple Regression Results

\begin{tabular}{lcc}
\multicolumn{1}{c}{ Variable } & Beta standards & Significance \\
\hline Economic opportunity & .420 & .013 \\
Challenge & .329 & .003 \\
Autonomy & .352 & .012 \\
Authority & .139 & .001 \\
Self-realization & .196 & \\
\hline F-Value & 21.47 & \\
R & .462 & \\
R square & .214 & \\
Adjusted R square & .18 &
\end{tabular}

\section{Discussion}

The study focused on identifying the reasons to choose entrepreneurship by B-school students in India and identified five factors viz., challenge, autonomy, self-realization, authority and economic opportunity. The main finding of the study is that these factors are strongly correlated with entrepreneurial intentions; furthermore the variables explained significant amount of variance leading to entrepreneurial intentions. Further, economic opportunity was strongest factor to explain the entrepreneurial intentions followed by autonomy, challenge, selfrealization and authority. The major implication of the study is that it contributes to literature of entrepreneurship and entrepreneurial intentions. Other researchers focused on entrepreneurial traits, behavior, and outcomes, but this paper empirically identified factors leading entrepreneurial intentions and their relationship with entrepreneurial intentions.

\section{Conclusion}

Entrepreneurial intention will create innovative, dynamic and sustainable economy and it is a prerequisite for economic growth [39], [40], [41], and [2]. B-school students are the future of business world as they will take charges of managers, CEOs, CFOs roles in the future therefore, understanding their intentions of entrepreneurship is very important. With this study we found that the proposed model significantly proves that five identified factors viz., challenge, 
autonomy, self-realization, authority and economic opportunity predicts the entrepreneurial intentions of B-schools students. Further, it reveals that entrepreneurial activity provides the Bschool students economic opportunity; expose them to challenges; gives autonomy to do what they want to do and authority. In the process they realize their potentials to excel in their endeavor to entrepreneurial success.

\section{Limitation}

There are many limitations to the current study as it was carried out on B-school students it cannot be generalized and also it is limited to geographical location of India which is a developing country. The results may vary for other students and country. Future studies could examine on these limitations and other courses like engineering, technology, science students and further focus on episodic entrepreneurship, social entrepreneurship, and start-ups could be carried out.

\section{Reference}

[1] Fisher, R., Maritz, A., \& Lobo, A. (2014). Evaluating entrepreneurs' perception of success. International Journal of Entrepreneurial Behavior \& Research, 20(5), 478-492.

[2] Fayolle, A., \& Linan, F., 2013. The Future of Research on Entrepreneurial Intentions. Journal of Business Research. 67(5), 663-666.

[3] Kuratko, D. F. (2005). The emergence of entrepreneurship education: Development, trends, and challenges. Entrepreneurship Theory and Practice, 29(5): 577-598.

[4] Solomon, G. (2007). An examination of entrepreneurship education in the United States. Journal of Small Business and Enterprise Development, 14: 168-182.

[5] Herbert E. \&Kierulff, Jr. (1971), Management Assistants Through Business Schools, Journal of Small Business Management.

[6] Shane, S., Locke, E. A., \& Collins, C. J. (2003).Entrepreneurial motivation. Human Resource Management Review, 13, 257-279.

[7] Bae, Tea Jun, Shanshan Qian, Chao Miao and James O. Fiet. (2014). The relationship between entrepreneurship education and EI: A Meta- Analytic Review, Entrepreneurship Theory and Practice, 38(2), 217-254.

[8] Shapero, Albert, and Lisa Sokol.(1982). "Social dimension of entrepreneurship" in C.A. Kent, D.L.Sexton, K.H.Vasper, eds., Encyclopedia of Entrepreneurship, pp.72-90, Englewood Cliff, NJ: Prentice Hall.

[9] Bandura, A. (1982). Self-efficacy mechanism in human agency. American Psychologist, 37(2), 122-147

[10] Ajzen, Icek. (1991). The theory of planned behavior, Organizational Behavior and Human Decision Processes, 50, 179-211.

[11] Ajzen, Icek and Martin Fishbein, (1980). Understanding attitude and predicting social behavior, Englewood Cliffs, NJ:Prentice Hall.

[12] Zhao, H., Seibert, S. E., \& Lumpkin, G. T. (2010).The relationship of personality to entrepreneurial intentions. Journal of Management, 36, 381-404. 
[13] Leutner, F., Ahmetoglu, G., Akhtar, A., \& Chamorro-Premuzic, T. (2014).The relationship between the entrepreneurial personality and the Big Five personality traits.Personality and Individual Differences, 63, 58-63.

[14] Gartner, William. (1988). "Who is an Entrepreneur?" Is the Wrong Question. Entrepreneurship Theory and Practice. 12.11-32. 10.1177/104225878801200401

[15] Gartner, William \& Shaver, Kelly \& Gatewood, Elizabeth \& Katz, Jerome. (1994). "Finding the Entrepreneur in Entrepreneurship". Entrepreneurship Theory and Practice. 18. 5-10. 10.1177/104225879201700110.

[16] Carland, JoAnn C.; Carland, James W.; Stewart, Wayne H.. Seeing What's Not THere: The Enigma of Entrepreneurship.Journal of Small Business Strategy, [S.1.], v. 7, n. 1, p. 120, jan. 1996. ISSN 2380-1751.

[17] Philip D. Olsen. (1985). Entrepreneurship: Process and Abilities. Entrepreneurship Theory and Practices. 10(1). pp.25-31.

[18] Carland, J. W., Hoy, F., Boulton, W. R. et al. (1984). Differentiating entrepreneurs from small business owners: A conceptualization. Academy of Management Review, 9, 354-359. [19] Herron L. and Sapienza H.J. (1992). The Entrepreneur and the Initiation of New Venture Launch Activities. Entrepreneurship Theory and Practice, 17(1). 49-55.

[20] Jeffery S. Hornsby, Douglas W. Naffziger, Donald F. Kuratko, Ray V. Montagno.(1993).An Interactive Model of the Corporate Entrepreneurship Process. Entrepreneurship Theory and Practices. 17(2).pp29-37.

[21] Bird, Barbara. (1988). Implementing Entrepreneurial Ideas: The Case for Intention. The Academy of Management Review. 13. 10.2307/258091.

[22] Douglas, Evan and Shepherd, Dean, Entrepreneurship as a Utility Maximizing Response (2000). Journal of Business Venturing, Vol. 15, Issue 3, p. 231-251 2000. Available at SSRN: https://ssrn.com/abstract=1510992

[23] Cruz, L.D., Suprapti, S., Yasa, K. (2015). Aplikasi Theory of Planned Behavior.

[24] Rauch, A., \&Frese, M. (2007). Let's put the person back into entrepreneurship research: A meta-analysis on the relationship between business owners' personalitytraits, business creation, and success. European Journal of Work and Organizational Psychology, 16, 353 385.

[25] Zacher, H., Biemann, T., Gielnik, M. M., \&Frese, M. (2012). Patterns of entrepreneurial career development: An optimal matching analysis approach. InternationalJournal of Developmental Science, 6, 177-187.

[26] L R. Tolentino, V Sedoglavich, V N Lu, P R J M Garcia, and S L D. Restubog, 2014, "The role of career adaptability in predicting entrepreneurial intentions: A moderated mediation model", Journal of Vocational Behavior 85 (403-412).

[27] Wach, D., Stephan, U., \& Gorgievski, M.J. (2016). More than money: Developing an integrative multifactorial measure of entrepreneurial success. International Small Business Journal, 34 (8), 1098-1121.

[28] McClelland, D. C. (1965). N achievement and entrepreneurship: A longitudinal study. Journal of Personality and Social Psychology, 1(4), 389392.http://dx.doi.org/10.1037/h0021956

[29] Nabi, G., \&Liñan, F. (2011). Graduate entrepreneurship in the de- ' veloping world: Intentions, education and development. Education 1 Training, 53(5): 325-334 
[30] Rideout, E. C., \& Gray, D. O. (2013). Does entrepreneurship education really work? A review and methodological critique of the empirical literature on the effects of universitybased entrepreneurship education. Journal of Small Business Management, 51(3): 329-351. [31] Shook, C. L., Priem, R. L., \& McGee, J. E. (2003). Venture creation and the enterprising individual: A review and synthesis. Journal of Management, 29, 379-399.

[32] Greene, F. J., \& Saridakis, G. (2008). The role of higher education skills and support in graduate self-employment. DOI: 10.1080/03075070802457082

[33] Stearns, T. M., and Hills, G. E. (1996) 'Entrepreneurship and new firm development: A definitional introduction', Journal of Business Research, 36, pp.1-4.

[34] Barringer and Ireland, (2009),Entrepreneurship: Successfully Launching New Ventures, 3rd Edition

[35] Turker D. and Selcuk S.S. (2009). Which factors affect entrepreneurial intention of university students? Journal of European Industrial Training, Vol.33. No.2,pp142-159.

[36] Amad, S.N.A., \& Damit, D.H.D.A.,(2016). Determinants of Entrepreneurial Intention among Undergraduate Students in Malaysia. Procedia Economic and Finance 37, 108-114.

[37] Zapkau, F.B., Schwens, C., Steinmetz, H., \& Kabst, R. 2015. Disentangling the effect of prior entrepreneurial exposure on entrepreneurial intention, Journal of Business Research, 68(3): 639-653.

[38] Yurtkoru, S. Kuscu, Z.K., \& Doganay, A. (2014). Exploring the Antecedents of Entrepreneurial Intention on Turkish University Students. Procedia- Social and Behavioral Sciences, 150: 841-850.

[39] Songul S G,\& Gor. Y.A, 2016, The Adventure of Women Entrepreneurship in Turkey: Is Success Possible. The Journal of Faculty of Economics and Administrative Sciences, Vol.21, No.4, pp.1361-1377.

[40] Urbano,D., \& Aparicio, S. (2015). Entrepreneurship capital types and economic growth: International evidence, Technological Forecasting and Social Change.

[41] Karimi, S., Biemans, H.J.A., Lans, T., Mulder, M. \& Chizari, M., 2014.The impact of Entrepreneurship Education: A Study of Iranian Students' Entrepreneurial Intentions and Opportunity Identification. Journal of Small Business Management.

[42] Reynolds, P.D. (1987). New firms - societal contribution versus survival potential. Journal of Business Venturing, 2(3), 231-246.

[43] Kolvereid, L. (1996a), 'Organizational employment versus self-employment: Reasons for career choice intentions', Entrepreneurship Theory and Practice, Vol 20, No 3, pp 23-31. [44] Autio, Erkko, Robert H. Keeley, Magnus Klofsten, George G.C. Parker and Michael Hay. (2001). Entrepreneurial intent among students in scandinavia and in the USA, Enterprise and Innovation Management Studies, 2(2), 145-160.

[45] Verheul, I., Thurik, R., Grilo, I., and van der Zwan, P. (2012), 'Explaining preferences and actual involvement in self-employment: Gender and entrepreneurial personality', Journal of Economic Psychology, Vol 33, No 2, pp 325-341.

[46] Katz, J.A. (1992), 'A psychological cognitive model of employment status choice', Entrepreneurship Theory and Practice, Vol 17, No 1, pp 29.37.

[47] Rose, P., Kodithuwakku, S., and Balunywa, W. (2008). 'Entrepreneurial motivation in developing countries: what does "necessity" and "opportunity" entrepreneurship really mean?', Frontiers of Entrepreneurship Research 2006, available at: SSRN:http/ssm.com/abstract=1310913 (accessed 10 March 2010). 
[48] Kolvereid, L. (1996b), 'Prediction of employment status choice intentions', Entrepreneurship Theory and Practice, Vol 21, No 1, pp 47-57.

[49] Fornell, C. and Larcker, D.F. (1981), “ Evaluating structural equation models with unobservable variables and measurement error”, Journal of Marketing Research, Vol.18 No.1, pp.39-50.

Table 1 Themes

\section{Themes}

1. I will get economic opportunity

2. I receive compensation (other)

3. I like to do exciting job

4. I like to do interesting work activities

5. I will be motivated to work as I like

6. I have freedom

7. I want to be my own boss

8. I want to choose my own work tasks

9. I have power to make decisions

10. I have authority

11. I realize to become an entrepreneur

12. I realize the capabilities to become an entrepreneur

13. I realize to own an enterprise

14. I realize to succeed in entrepreneurial activities

Table 2 KMO and Bartlett's Test for sample adequacy

Kaiser-Meyer-Olkin Measure of Sampling Adequacy..744

Bartlett's Test of Sphericity $\quad$ Approx. Chi-Square $\quad 958.290$

df $\quad 105$

Sig. $\quad .000$ 
Table 3 Factor loading

Statement Challenge (F1) Autonomy (F2) Self-realization (F3) Authority

(F4) Economic Opportunity (F5)

1. I will get economic opportunity

2. I receive compensation (other)

3. I like to do exciting job .871

4. I like to do interesting work activities

5. I will be motivated to work as I like

6. I have freedom

.873

7. I want to be my own boss

8. I want to choose my own work tasks

9. I have power to make decisions

10. I have authority

11. I realize to become an entrepreneur

.650

12. I realize the capabilities to become an entrepreneur

13. I realize to own an enterprise

14. I realize to succeed in entrepreneurial activities

Cronbach's Alpha

$\begin{array}{llll}.842 & .753 & .733 & .799\end{array}$

.766

Table 4. The Cronbach's alpha and AVEs

\begin{tabular}{|c|c|c|c|}
\hline Constructs & Cronbach's alpha & AVE & Square \\
\hline AVE & & & \\
\hline $\begin{array}{l}\text { Challenge } \\
0.831\end{array}$ & 0.842 & 0.692 & \\
\hline $\begin{array}{r}\text { Autonomy } \\
0.885\end{array}$ & 0.753 & 0.784 & \\
\hline $\begin{array}{l}\text { Self-realization } \\
0.845\end{array}$ & 0.733 & 0.715 & \\
\hline $\begin{array}{l}\text { Authority } \\
0.891\end{array}$ & 0.799 & 0.794 & \\
\hline $\begin{array}{c}\text { Economic opportunity } \\
0.856\end{array}$ & 0.766 & 0.734 & \\
\hline
\end{tabular}




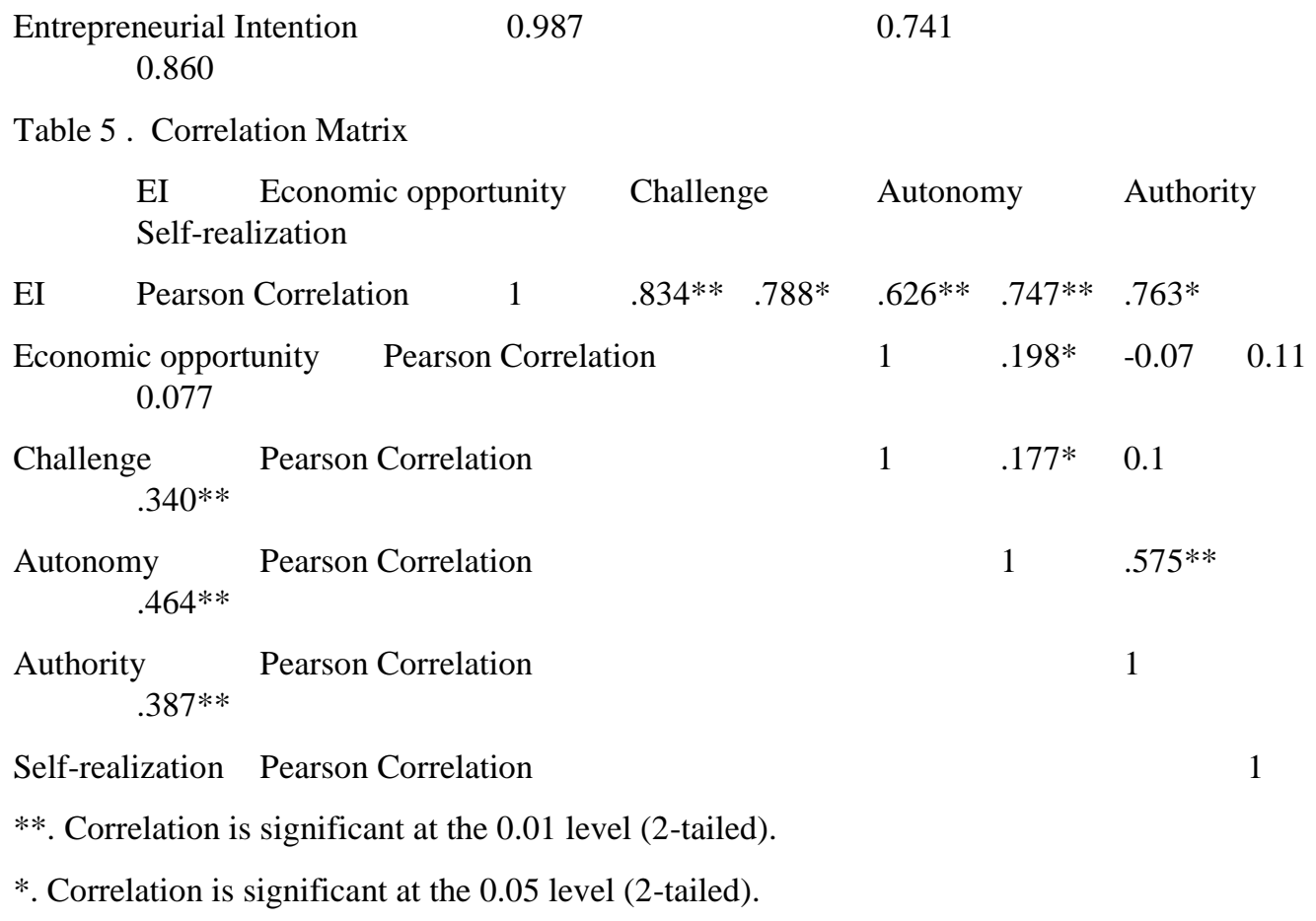

Table 6 Multiple Regression Results

\begin{tabular}{|c|c|c|}
\hline Variable & Beta standards & Significance \\
\hline $\begin{array}{l}\text { Economic opportunity } \\
.013\end{array}$ & .420 & \\
\hline $\begin{array}{l}\text { Challenge } \\
.003\end{array}$ & .329 & \\
\hline $\begin{array}{l}\text { Autonomy } \\
.012\end{array}$ & .352 & \\
\hline $\begin{array}{l}\text { Authority } \\
.001\end{array}$ & .139 & \\
\hline $\begin{array}{l}\text { Self-Realization } \\
.000\end{array}$ & .196 & \\
\hline F value & 21.47 & \\
\hline
\end{tabular}


$\mathrm{R}$

R square

Adjusted R square 